\title{
Protein Evaluation of Foods
}

\author{
Malomo Olu*, Alamu Ezekiel Adediran \\ Department of Food Science and Nutrition, Bells University of Technology, OTA, Ogun State, Nigeria
}

Email address:

oludaremalomo1951@yahoo.com (M. Olu)

\section{To cite this article:}

Malomo Olu, Alamu Ezekiel Adediran. Protein Evaluation of Foods. International Journal of Nutrition and Food Sciences. Vol. 4, No. 6, 2015, pp. 700-706. doi: 10.11648/j.ijnfs.20150406.26

\begin{abstract}
The measurement of protein quality is usually non-specific, that is, if one compares this with the assay for minerals, one would find that in the case of minerals, a specific substance is being measured. However, with proteins, the quality depends on the quantity of at least 9 amino acids. The quality of the protein depends on the balance among the respective amino acids, on which the utilisation of the protein depends. As a result, the different methods of protein evaluation give different results for the nutritive value.
\end{abstract}

Keywords: Protein Evaluation, Biological Value, Essential Amino Acids Index, Protein Efficiency Ratio,

Net Protein Retention, Dinitro-Benzene

\section{Bioassay of Protein Quality}

The biological evaluation of protein quality is usually carried out using rats.

In 1919, Osborne et al. (1919) introduced the term Protein Efficiency Ratio (PER), a biological method based on the expression of growth-promoting value of protein numerically. This hypothesis proposed by Osborne and his co-workers was the "optimum of the protein which is determined not only by the absolute amount furnished, but also by its quality". From this work, it was observed that protein sources could be evaluated by simply comparing the relative weight gain of an animal fed the material in relation to the actual amount of protein consumed. According to Bender (1956) this was considered the simplest and most convenient method of measuring the nutritive value of proteins.

The protein efficiency ratio has been frequently criticized and Mitchell (1924) stated that simplicity was its only recommendation. There are two main drawbacks to the method. Firstly, protein efficiency ratio as measured on any protein increases with the quantity consumed (Mitchell, 1924; Barnes et al., 1945). It should be noted that a certain amount of protein is required for maintenance of body weight, and only the increment above this amount is available for growth. Consequently, when larger quantities are consumed, more is available for growth and a higher protein efficiency ratio (PER) results. Secondly, the method is based on the assumption that the increase in the body weight on the protein containing diet is proportional to the protein retained. It has been repeatedly shown that the composition of the weight increases varies with the type of diet during 6-8 weeks of the usual experiments (Hamilton, 1939).

The protein efficiency ratio is open to other criticisms. Bender and Doell (1957) pointed out that gain in body weight is constant in composition is not valid. They argued further that the result may vary with the level of protein in the diet, and that the results are influenced by food intake. Moreover, no allowance is made for maintenance; it is assumed that all the protein consumed is used for growth. The method ascribes a value of zero to protein that do not that permit growth. To correct the dependence of protein efficiency ratio on food intake Bender and Doell (1957) proposed the use of a slope ratio method whereby weight loss of a control group of animals given a protein free diet as well as the weight gain of the test group are considered. This slope-ratio method was put forward in an attempt to overcome some of the problems in the protein efficiency ratio. It requires the testing of protein at several levels in an effort to give an estimate of the precision and validity of assay. However weight loss of the rat fed a non protein diet id equivalent to the protein needed for maintenance. In an argument put forward by Mclaughlan and Keith (1975) to criticize the slope ratio method of Bender and Doell (1957), they assumed a straight line relationship involving the weight loss of the non-protein group of rats proposed by Bender and Doell (1957), and other levels of dietary protein. The results of the slope-ratio method, otherwise known as the net protein retention value (NPR), at any point of the curve, remained constant, while on the other 
hand the protein efficiency ratio varied along the curve. However, this straight line relationship is an ideal situation. It is not the usual form of the response curve. Typically, the response curve is not straight but deflects downwards, cutting the $y$-axis at a point less negative that the weight loss of the non-protein group. Hence the net protein ratio values tend to fall with increasing protein intake.

Another modified assay also known as the slope ratio method, which is an extension of the previous method of Bender and Doell (1957), was put forward by Hegsted and Chang (1957) to avoid problems resulting from non-linear response. This slope-ratio assay is a multiple dose (protein level) method, which they termed relative nutritive value (RNV). Here three or four levels of the test protein are fed, but only the points falling on the linear portion of the curve are used in calculating the slope of the response line. The slope of the response line for the test protein is expressed as a percentage of the slope of a reference protein. Mclaughlan (1972) reported that the slope ratio method gave invalid assays for lysine-deficient proteins. Moreover, the inclusion of the non-protein group in the calculation of the slope of lysine-deficient protein group seriously skews the slope. A more complex method of evaluating protein in diets is the measurement of Biological Value (BV). This is the currently much sued method for assessing protein quality. This is calculated from nitrogen intake and nitrogen excreted by the experimented animal. This concept was first introduced by Thomas (1909), who measured this value in adult humans. The procedure was later refined by Mitchel (1923-24) and Mitchel et al. (1945), who used growing rat and measured the requirements for both maintenance and growth. In the utilisation of nitrogen, mixtures of amino acids are involved. When the individual amino acids are absorbed, the excess over the amount needed may be deaminated and the nitrogen component of the amino acids excreted in the urine. The calculation of biological value, using the Thomas-Mitchel expression, is as follows:

$$
\begin{gathered}
\mathrm{BV}=\frac{N I-(F N-F M N)-(U N-U N e)}{N I-(F N-F M N)} \times 100 \\
\mathrm{NI}=\text { Total nitrogen iontake } \\
\mathrm{FN}=\text { Total faecal nitrogen } \\
\mathrm{FMN}=\text { Metabolic faecal nitrogen } \\
\mathrm{UN}=\text { Total urinary nitrogen }
\end{gathered}
$$$$
\mathrm{UNe}=\text { Endogenous urinary nitrogen }
$$

The calculation of biological value (BV) by the Thomas-Mitchell method includes the correction of the total faecal nitrogen for metabolic faecal nitrogen. The urinary nitrogen excreted is also corrected for the endogenous nitrogen. But the cutaneous losses of nitrogen was ignored.

There are two serious limitations to the use of the Thomas-Mitchell expression as a practical method:

1. It is difficult to measure the endogenous urinary nitrogen.
2. The level of dietary protein does not alter the result. To eliminate this, the level of 100 percent in the diet is normally used as standard (Hamilton et al., 1952). As a practical measure, the apparent $\mathrm{BV}$ is sometimes measured according to the following formula:

$$
\begin{gathered}
\text { Apparent BV }=\frac{N I-(F N-U N)}{N I} \times 100 \\
\mathrm{NI}=\text { Total nitrogen intake } \\
\mathrm{FN}=\text { Total faecal nitrogen } \\
\mathrm{UN}=\text { Urinary nitrogen }
\end{gathered}
$$

The biological nitrogen value method is time consuming and cumbersome. Bender and Miller (1953) introduced the term net protein value (NPV), but Miller and Bender (1955) later referred to the method of the nitrogen retained and that of the nitrogen intake, multiplied by 100 . It is numerically the product of the biological value and digestibility.

$$
(\mathrm{NPU})=\frac{\text { Nitrogen retained }}{\text { Nitrogen intake }} \times 100=\text { Biological value } \times 100
$$

They determined NPU with a group of rats after a period of ten days on test protein and nitrogen and nitrogen-free diet which provide the endogenous nitrogen, while nitrogen deposited as new tissue by animals on test diets was determined with reference to the total nitrogen consumed. The NPU therefore estimates the function of the food nitrogen that is retained by the rats. Mclaughan and Keith (1975) described rat bio-assays for protein quality to be essentially a measure of the amount of the limiting amino acid available to the test animal. They argued that since the limiting amino acid differs from protein to protein, it is possible to be measuring one amino acid in one protein, and a different amino acid in another protein. They further stressed that matters could be complicated if there to be difference in the limiting amino acid, depending upon the level of protein in the diet.

In the final analysis, one thing that is certain is that no rat bio-assay method for evalasting protein quality will ever be completely satisfactory as a predictor of nutritional value for the human diet.

\section{Chemical Methods}

Many procedure using chemical composition have been applied to evaluation of protein. Mitchell and Block (1946) devised a system of "chemical scores" based on the amount of the essential amino acids in a protein compared to the level present in a reference protein selected for its nutritional excellence. Mitchell (1954a) found chemical scores to have a high degree of correlation $(\mathrm{r}=0.95)$ with published biological values of food proteins. However, Mitchell (1954a and b) pointed out in his works that biological values of foods depends on the content of essential amino acids, and that chemical score is an index of the value of protein for growth only, because he assumed that the absence of an essential amino acid renders the protein completely unavailable even 
for tissue maintenance. This assumption was not consistent with observations reported by Mason and Palmer (1935).

Shelling (1975) argued that the chemical score procedure simply involves expressing the amount of each indispensable amino acid in the test protein as a percent of that in whole egg. A lower chemical score, he further stated thereby represents a lesser amount of that amino acid relative to the amount required. However, Rao et al. (1964) concluded that the establishment of reliable rat amino acid requirements has led to their as a reference for chemical score, calculated according to Mitchell and Block (1946), using the requirement pattern as the standard, and the biological values of 15 proteins to be highly significant $(\mathrm{r}=+0.89)$. This they found to be compare well with that $(r=+0.846)$ reported by Mitchell (1954a) using egg protein as standard.

Oser (1959), in his contribution to protein evaluation using amino acid analysis, stated that each amino acid may be considered as a keystone in an arch, without which a stable protein structure cannot be built. Accordingly, the rating of a protein for nutritional quality should take into account its entire contribution of essential amino acids, not merely the one in greatest deficit with respect to a nutritional standard. $\mathrm{He}$ therefore devised a means of representing the entire essential amino acid spectrum of a protein by an integer termed the essential amino acid index (EAAI). The essential amino acid index derivation was based on two assumptions, that the minimum ratio of essential amino acid content relative to that of standard protein is one percent, and that the maximum is 100 percent. Oser (1959) defined this mathematical model as the geometric mean of "the egg ratio", that is, the ratios of the essential amino acids in a protein relative to their respective amounts in whole egg protein:

$$
\text { EAA Index }=\mathrm{n} \sqrt{\frac{\text { lysine } P}{\text { lysine } S} \times \frac{\text { tryptophan } P}{\text { tryptophan } S} \times \frac{\text { histidine } P}{\text { histidine } S}}
$$

Subscript $\mathrm{p}=$ food protein

$\mathrm{S}=$ standard protein (whole egg)

$\mathrm{N}=$ number of amino acids (counting pairs such as menthionine and cystine as one )

In this same work work, Oser (1959) suggested calculating the egg ratio for each individual amino acid and using these values in the computation of the essential amino acid indexes. He further suggested that, on occasions when certain amino acid values are not available, they could be omitted, provided that the appropriate ' $n$ ' is not used.

A high degree of correlation between essential amino acid indexes (EAAI) and biological values was found. Form the EAA indexes, he derived an equation for calculating the biological value (Oser, 1959):

$$
\text { Biological value }=1.09(\text { EAAI })-11.7
$$

The correlation between the EAA index and the biological value was so consistently high that Oser finally concluded that estimates of the latter may be from essential amino acid assay with a degree of reliability greater, in the long run, than is obtainable in the usual biological assay using 10 rats per group. However, whether the results give useful information depends on the availability to the animal organism of the determined amino acids. He found that factors such as heat treatment or insolubility, which antagonise the degree or rate of digestibility and absorption of protein, do cause complication in the interpretation of results.

Rao et al. (1964) argued that essential amino acid requirements should serve as a standard for evaluating the quality of protein in foods, rather than the total essential amino acids content of the food. This led to the development of a mathematical model based on the calculation of the geometrical mean of essential amino acids, each expressed as a percentage of its minimal requirements, except that values exceeding 100 percent are reduced to 100 percent. This mathematical model they called protein requirement index.

In this method, the minimal requirements for the essential amino acids and the optimal protein level for maximal growth and body nitrogen retention of the growing rat was used.

Kapour and Heiner (1982), using the essential amino acid index (EAAI), calculated biological value and requirement index to evaluate changes in developing wheat adn found a high correlation $(\mathrm{r}=+0.884)$ between the calculated biological value method of Oser (1959) and the requirement index method of Rao et al. (1964).

According to Eggum (1968), chemical assay methods are of limited value for the analysis of protein quality because digestibility and biological digestibility of the proteins are overlooked. However, Said and Hegsted $(1969,1970)$ found that net protein utilisation and biological value using animal studies are unsatisfactory methods for assessing the protein value of grains for humans. Thus the chemical methods used in the present study are quite useful supplements to the biological methods, and are particularly valuable in predicting amino acid deficiency.

\section{Amino Acids}

Of the 22 amino acids known to be physiologically important, the body is capable of synthesizing some under proper conditions and if a supply of nitrogen is made available. These groups of amino are known as the dispensable, or non-essential amino acids. The rest cannot be synthesized by the body and must be therefore be supplied by diet. These are indispensable or essential amino acids: leucine, isoleucine, lysine, phenylalanine, methionine, tryptophan, valine and threonine. Histidine may be added to theses as it appears to be essential to the growth of infants. When arginine is added to the latter group to make a total of 10 , they are considered essential for the growth rat and chick. The previously mentioned 8 are essential for human adults (Rose et al., 1949; Mitchell, 1959).

Amino acid analysis, using ion exchange chromatography, has been favoured in this. Walker (1981) regarded it as one of the most important chemical techniques for predicting protein quality. However, since the chemical score obtained from 
amino acid analysis data may over-estimate protein quality, values for digestibility and amino acid availability are now incorporated in the score. An additional problem is that the acid hydrolysis, which is necessary for sample preparation, destroys tryptophan, and may give low values for sulphur containing amino acids. Bender (1961) had found that, despite the limitations, chemical score based on amino acid analysis is capable of judging protein quality accurately when compared with rat assay, provided the analysis is carried out carefully.

One other factor that can affect the validity of amino acid data is the way they are calculated. Blackburn (1978) suggested the addition of an internal standard of norleucine to the amino acid hydrolysates in order to make corrections for recovery losses.

\section{Amino Acid Availability}

The nutritional quality of the proteins of most foodstuffs is dependent largely on two essential amino acids, lysine and tryptophan. However, methionine, threonine and isoleucine may also be quite low in several foodstuffs. These amino acids are frequently referred to as the critical amino acids, the most deficient in relation to the standard protein being called the first-limiting amino acid (Concon, 1975).

Chemical methods for determination of amino acid availability are almost entirely restricted to the estimation of available lysine. Most of the methods are based on the estimation of free $\epsilon$ - amino group of lysine in the intact protein. The nutritional availability of lysine has been based on the assumption that these groups are free to react chemically. Lysine in its reactive (available) form is reported to be the first-limiting essential amino acid to be rendered unavailable during processing, or even prolonged storage under certain conditions (Carpenter, 1974; Concon, 1975). Thus lysine may easily deaminate, be exidised, or undergo the browning reaction. Therefore its availability can be used to monitor processing damage, and other unit operations.

The most widely used chemical test for the estimation of the lysine is based on the reaction of the $\in$-amino group of lysine with 1-fluoro-2, 4-dinitro benzene (FDNB).

A procedure for the estimation in foods of the lysine units whose $\in$-amino -amino group will undergo reaction with fluorodinitrobenzene (FDNB), as illustrated in figure 3, was developed by Carpenter and Elinger (1955). Any lysine residue which is already bound with another group through its $\epsilon$-amino group is not free, which is available for reaction with the reagent, produce a yellow dinitrophenyl derivative (DNP), which can be estimated colorimetrically after acid hydrolysis.

According to Bruno and Carpenter (1957), $\alpha$-DNP-arginine-, $\gamma$-DNP ornithine and water-soluble breakdown products from the other DNP -amino acids still remained in the aqueous phase along with the $\in$-DNP-lysine. A modification was introduced by these workers to correct for these error. The colour contributed by theses compounds was estimated after removal of the $\in$-DNP-lysine from the aqueous phase. Reaction of the yellow aqueous phase with methoxy carbonyl chloride changed the $\in$-DPN-lysine into another soluble derivative, the interfering compounds remaining water soluble. Colorimetric measurement of the yellow aqueous phase before and after treatment with methoxycarbonyl chloride and other extraction accordingly gives an estimate of the colour contributed by the impurities.

The correction for the loss of $\in$-DNP lysine produced during hydrolysis was carried out by Carpenter (1960). He measured the recovery of $\in$-DNP lysine added to the DNP protein immediately before the hydrolysis stage. An average value of 92 percent was found. He then ccorrected his available lysine value on this basis, with the assumption that free $\in$-DNP-lysine similarly on hydrolysis to $\in$-DNP -lysine in proteins.

Booth (1971) found that added $\in$-DNP- lysine was partly destroyed during acid hydrolysis, but protein bound DNP-lysine was destroyed to a lesser extent. The differences in destruction of added $\in-D N P$ lysine was considered to be due to the DNP -protein being less soluble than $\in$-DNP-lysine and so less readily susceptible to reduction by breakdown products of carbohydrates. The latter are produced in early stages of acid hydrolysis, where $\in$-DNP lysine is only slowly released from DNP - protein. The breakdown products of carbohydrates quickly react with soluble nitrophenyl compounds and are mostly removed by the time that an appreciable amount of $\in$-DNP- lysine has been released from the protein.

Carpenter's method is well established from measuring available lysine in animal protein products; difficulties are encountered when it is applied to cereal grains and legumes. These are manifested as poor recoveries of $\in$-DNP-lysine and variable results. The reasons for the poorer performance of the method on these materials are associated with the destruction of $\in$-DNP-lysine by carbohydrate during hydrolysis and the formation of other yellow products which are not easily separated from $\in$-DNP-lysine (Bruno and Carpenter, 1957; Rao et al., 1963). Rao et al (1963), using Carpenter's hydrolysis technique followed by ion exchange chromatography to isolate, $\in$-DNP-lysine formed, found that a good recovery adn reproducibility with cotton seed meals. Roach et al (1967) measured available lysine in high protein animal and vegetable meals using a semi-automatic method based on the measurement of total lysine and the lysine remaining after treatment of the meals with fluorodinitrobenzene according to the Carpenter method. The difference between these two values represents the lysine in the protein which has free $\in$-amino group and is expressed as available lysine. Their results compared well with those of the established method of Carpenter (1960) and Rao et al. (1963).

Carpenter (1960) recommended that a correction factor of 1.09 should be used for animal and fish proteins to compensate for and average recovery of 92 percent. Roach et al. (1967), on the other hand, made individual corrections based on the actual recoveries samples, and that the variability of the recoveries increased the standard deviation over that of the uncorrected results. This evidence therefore makes the use of an average correction factor recommended by Carpenter (1960) questionable.

Walker (1979b), using the Carpenter (1960) method, as modified by Booth (1971), found that the FDNB-reactive lysine was highly correlated $(\mathrm{r}=+0.90)$ with the dye-binding reactive-lysine method. Dye-binding, using acid dyes at low $\mathrm{pH}$, primarily involves the formation of ionic linkages with the 
basic amino acids (lysine, histidine and arginine) present in protein, as well as with terminal amino groups (Walker, 1979a).

Others have attempted to separate DNP-lysine from interfering amino acids and other compounds formed during hydrolysis of carbohydrate containing food by paper chromatography (Balinga et al., 1959), thin layer chromatography (Holm, 1971), or liquid-liquid partition chromatography (Blom et al., 1967).

Peterson and Wartesen (1979) also attempted to use high pressure liquid chromatography (HPLC) to determine available lysine using a modification of Carpenter's (1960) method.

The laboratory evaluation of protein quality in terms of lysine availability using the Carpenter (1960) chemical method is found relatively simple and accurate. Hence the use has been favoured in the present study for protein quality measurement.

\section{In-Vitro Digestibility}

Chemical score and amino acid index procedures, widely used for evaluating the protein quality of foodstuffs, have been earlier reviewed. Although these procedures are rapid, and in many cases accurate; however, no allowance was made for variations in digestibility and availability of the amino acids. Various methods have been proposed for the in-vitro evaluation of digestibility.

The enzyme system developed by Sheffner et al. (1956) involved determining the essential amino acids released by in-vitro pepsin digestion and those in the remainder of the protein to calculate a "pepsin-digest residue (PDR) amino acid index.

Saunders et al. (1973), in their in-vitro digestibility of protein studies using pepsin, pepsin-pancreatin and pepsin trypsin methods, found that values obtained with either system involving pepsin showed a high degree of correlation with protein digestibility values obtained in rat feeding trails.

Hsu et al. (1977) developed a rapid multi-enzyme technique for estimating protein digestibility. The multi-enzyme system consisted of trypsin, chymotrypsin and peptidase. They found that the $\mathrm{pH}$ of a protein in suspension immediately after digestion for 10 minutes with the multi-enzyme solution was highly correlated with the in-vivo apparent digestibility in rats. Regression analyses of 23 samples tested by these workers showed that the correlation coefficient between $\mathrm{pH}$ at 10 minutes and in-vivo apparent digestibility was 0.90 with a standard error estimate of 2.23. The regression equation obtained was $\mathrm{Y}=210.464-18.103 \mathrm{X}$, where $\mathrm{x}$ was the $\mathrm{pH}$ of protein suspension immediately after 10 minutes digestion with the multi-enzyme solution. They claimed that the most significant advantage of this in-vitro method for prediction apparent protein digestibility over others was that it would be completed within one hour and with a high degree of sensitivity. They also claimed that the method could detect the effects of trypsin inhibitor, chlorogenic acid and heat treatment on protein digestibility. Although strong buffer salts may affect the measurement of protein digestibility, the buffering effects found in general food proteins and product tested did not create any problem with this procedure.

Walker (1981) found a high correlation $(r=+089)$ between in-vitro digestibility using the Saunders et al. (1973) method, and available lysine by dye-binding with 7 various leaf protein concentrates. The protein digestibility of Saunders et al. (1973) was used in the present study, because of its high correlation with bio-assay methods and other chemical methods of investigating protein quality, as reported by Walker (1981).

\section{Energy - Protein Relationships}

The estimates of protein requirements are valid only when energy requirements are fully met. When the total energy intake is inadequate, some dietary protein is used for energy and is not available to satisfy protein needs. The further increase in protein intakes to meet safe levels is of limited efficiency and wasteful, if energy needs are not met at the same time (FAO/WHO, 1973).

The maximum intake of dietary protein necessary to achieve nitrogen balance depends not only on the amino acid composition and the digestibility of the protein, but also on the composition and adequacy of the diet as a whole (Young and Scrimshaw, 1978). Among the most important dietary factors that affect dietary nitrogen retention are:

i. The quantity of protein and non-protein energy in the diet

ii. The amount of total nitrogen

iii. The intake of essential amino acids.

The interactions between dietary protein and energy intake have been the subject of many studies in humans as well as in farm and laboratory animals (Richardson et al., 1975).

Studies with humans (Young and Scrimshaw, 1978; Wilmore, 1977) indicate that protein metabolism is highly sensitive to energy intake, the level of energy intake influencing the estimated minimum requirement for dietary protein, and the effects of energy and protein intakes have important implications for quantitative estimation of human protein amino acid requirements (Garza et al., 1973).

Calloway (1980) found that, in both children and adults, male and female, increasing energy of the diet from marginally sub-maintenance levels to luxus levels resulted in a more positive or less negative balance. It was argued that this effect requires the presence of sufficient protein of adequate quality to allow $\mathrm{N}$ balance.

This study investigated changes in energy-protein ratio in germinating grains and the effect of processing on this ratio.

\section{References}

[1] AKESON, W. R., AND STAHMAN M. A. (1964). A pepsin pancreatin digest index of protein quality evaluation. J. Nutri. $83 ; 257$.

[2] BALINGA, B. P., BAYLISS M. E. And LYMAN C. M. (1959). Determination of free lysine $\in$-amino groups in cotton seed meals and preliminary studies on relation to protein quality. Arch. Biochem. Biophys. 84: 1. 
[3] BENDER, A. E. And MILLER, D.S. (1953). A new brief method of estimating rat protein value. Biochem. J. 53, VII-VII

[4] BENDER, A. E. (1971). Processing damage to protein foods. Paper presented at 18th PAG. Meeting Room (1971), PAG BULL., p. 10.

[5] BENDER, A. E. And DOELL, B. H. (1957). Biological evaluation of protein; a new aspect. Brit. J. Nutri. 11: 140

[6] BENDER, A. E. (1961). Determination of nutritive value of protein by chemical analysis. In: Meeting protein needs of infants and children pub. 843. National Academy of Sciences. Nat. Research Council, Washing, D. C. Pp 407.

[7] BLOM., HENDRICKS, P. and CARLS, J. (1967). Determination of available lysine in foods. Anal. Biochem. 21: 382 .

[8] BOOTH, V. H. (1971). Problems in the determination FDNB available lysine. J. Sci. Food Sci. 40: 266

[9] BRUNO AND CARPENTER, R. J. (1957). A modified procedure for the estimation of available lysine in protein. Biochem. J. 67: 13.

[10] CARPENTER, K. J. (1960). The estimation of available lysine in animal protein foods. Biochem. J. 77: 604.

[11] CARPENTER, K. J. (1974). Chemical and Microbial assays for the evaluation of processed protein foods. In: Nutrients in processed food proteins. American Medical Association (eds. P. L. White and D. C. Fletcher). Action, Massachussetts. Pub. Sciences Group Inc.

[12] CALlOWAY, D. H. (1980). Energy-protein relations. Unpublished. Univerty of Carlifornia, Berkley. Dept. Of Nutritional Sciences, Berkley Ca. (Obtained from Dr. Richardson, Lord Zucherman Laboratory, University of Reading, Reading)

[13] CONCON, J. M. (1975). Chemical determination of critical amino acids in cereal grainsa dn other foodstuffs. In: Protein nutritional quality of foods and feeds. Part 1 (ed. M. Friedman). Marcel Dekker Inc., New York.

[14] EGGUM, B. D. (1968). Evaluation of protein quality and the development of screening techniques. Panel on new approaches to breeding for plant protein improvement held at Svalof, Sweden, 17-21 June 1968

[15] GARZA C., et al (1973). Human protein requirements evaluation of the $1973 \mathrm{FOA} / \mathrm{WHO}$ safe level of protein intake for young men at high energy intakes. Brit. J. Nutr. 37: 403

[16] HAMILTON, T. S. (1939). The growth, activity and composition of arts fed diets balanced and unbalanced with respect to protein. J. Nutr. 17: 565.

[17] HS,U H. W., VARAK, D. L., SATHERLEE, L. D. And MILNER, G. A. (1977). A multi enzyme technique for estimating protein digestibility. J. Food. Sci. 42: 42: 1269.

[18] HEGSTED, D. M. and CHANG Y. O. (1965). Protein utilisation in growing rats. 1. Relative growth index as a bioassay procedure. J. Nutr. 85: 159.

[19] HOL M, H. (1971). Micro-method for determination of non-N-terminal lysine in milk and similar products. J. Sci. Food Agric. 22: 378.

[20] KAPOUR, A. C. And HEINER R. E. (1982). Biochemical changes in developing wheat grains. Changes in nitrogen fractions, amino acids and nutritional quality. J. Sci. Food Agric. 33: 35.

[21] MASON, I. D. and PALMER L. (1935). Utilisation of gelatine, casein and zein by adult rats. J. Nutri. 9: 489.

[22] McLANGHLAN, J. M. (1972). Nutritional evaluation of proteins by biological methods. Cereal Sci. Today 117: 162 .

[23] McLANGHLAN, J. M. and KEITH M. O. (1975). Bioassays for protein quality. In: protein nutritional quality of foods and feeds. Vol. I (ed. M. Friedman). Marcel Dekker Inc., New York.

[24] MILLE,R D. S. and BENDER, A. E. (1955). The determination of the net utilisation of proteins by a shortened method. Brit. J. Nutri. 9: 382 .

[25] MALOMO, O. (1982). Protein evaluation of foods. In. Germination as a unit: Its application in the development of a cereal-legume food product. PhD Thesis, University of Reading, UK.

[26] MITCHELL, H. H. And BLOCK, R. J. (1946). Some relationship between the amino acid content of protein and their nutritive value for the rat. J. Biol. Chem. 163: 599.

[27] OSBOURNE, T. B. And MENDEL, L. B. (1919a). Nutritive properties of proteins of maize kernel. J. Biol. Chem.. 18: 1.

[28] OSER, B. L. (1959). An integrated essential amino acid index for predicting the Biological value of proteins. In: Protein and amino acid nutrition (ed. A. A. Albanese). Academic Press, New York PP 281.

[29] RAO, S. R., CARTER F. C., and FRAMPTON V. L. (1963). Determination of available lysine in oil seed meal proteins. Anal. Chem.. 35: 1927.

[30] RAO, P. B. R., NORTON H. W. And JOHNSN, B. C. (1964). The amino acid composition and nutritive value of proteins. V. The amino acid requirements as a pattern for protein evaluation. J. Nutr. 82: 88 .

[31] RICHARDSON et al (1975). Quantitative effect of an iso-energetic exchange of fat for carbohydrate on dietary protein utilisation in healty young men. Amer. J. Clinical Nutr. 32: 2217.

[32] ROACH, A. G., SANDERSON, P. And WILliaMS, D. R. (1967). Comparison of methods for the determination of available lysine values in animal adn vegetable protein sources. J. Sci. Food Agric. 18: 274.

[33] SAID, A. K. and HEGSTED, D. M. (1969). Evaluation of dietary protein quality in adult rats. J. Nutr. 99: 474.

[34] SAID, A. K. and HEGSTED, D. M. (1970). Response of adult rats to low dietary levels of essential amino acids. J, Nutr. 100: 1363.

[35] SAUNDERS et al (1973). Measurement of digestibility of alfalfa protein concentrates by vitro methods j. Nutr. 103: 530 .

[36] SCHELLING, G. T. (1975). An efficient procedure for the complet evaluation of dietary proteins. In: Protein Nutritional quality of foods and feeds. Vol. 1 (ed. M. Friedman). Marcel Dekker Inc., New York. P. 137.

[37] SHEFFENER, A. L., ECKFELDT, G. A. and SPECTOR, H. (1956). The pepsin digest residue (PDR) amino acid index of net protein utilisation. J. Nutr. 60: 105. 
[38] WALKER, A. F. (1979a). Determination of protein and reactive lysine in leaf protein concentrate by dye binding. Br. J. Nutr. 42: 445.

[39] WALKER, A. F. (1981). The application of in-vitro methods to the estimation of protein quality of leaf protein concentrates. $\mathrm{PhD}$ Thesis, University of Reading, England.
[40] YOUNG, V. R. and SCRIMSHAW, M. S. (1978). Nutritional Evaluation of proteins and protein requirements. In: Protein Resources and Technology (ed. M. Milner, M. S. Scrimshaw and D.I. C. Wang). Westport, Connecticut. AVI Publishoing Co., p. 136. 